\title{
Assessment of the Effects of Wood Processing Industries in Selected Parts of Delta State, Nigeria, On the Soils and Vegetation in Their Vicinities
}

\author{
Osakwe .A. Stephen \\ Department Of Chemistry, Delta State University, Abraka, Delta State, Nigeria.
}

\begin{abstract}
Soil and vegetation samples collected from the vicinities of wood processing industries from selected parts of Delta State, Nigeria were analyzed for their metal levels and physicochemical properties inorder to assess the impact of the industries on the surrounding environment. The $p H$ values ranged from 4.9 to 6.0 indicating that the soils were acidic. The electrical conductivity values ranged from 54.80 to $75.90 \mathrm{uScm}$ which is suggestive of significant concentration of soluble inorganic salts. The total organic carbon and total nitrogen ranging from 0.25 to $0.45 \%$ and from 0.11 to $0.69 \%$ respectively showed some presence of degradable and compostable materials as well as organic matters in the soils. The cation exchange capacity which ranged from 1.23 to $3.95 \mathrm{cmolkg}^{-1}$ indicated the low capacity of the soils to adsorb metals. The mean levels of the heavy metals in the soils ranged from 12.69 to $272 \mathrm{mgkg}^{-1}$ with abundance trend of $\mathrm{Fe}>\mathrm{Mn}>\mathrm{Cu}>\mathrm{Zn}>\mathrm{As}>\mathrm{Cr}>$ $\mathrm{Pb}>\mathrm{Cd}$ while those of the vegetation ranged from 4.17 to $47.10 \mathrm{mgkg}^{-1}$ with abundance trend of $\mathrm{Fe}>\mathrm{Mn}>\mathrm{Zn}$ $>\mathrm{Cu}>\mathrm{Cr}>\mathrm{Pb}>$ As. The metal levels in both the soil and vegetation samples in all the sites were significantly higher than the levels obtained in the control site which is suggestive of significant contribution of the industries to these elevated levels. The contamination/pollution index values of the metals in the soil samples showed generally contamination levels for all the metals except copper which showed moderate pollution. The soil plant transfer values indicate medium, accumulation for all the metals. Although the overall results showed evidence of contamination of the soils by heavy metals, the present levels do not pose any environmental risk or health hazard.
\end{abstract}

Key Words: Heavy metals; Physicochemical characteristics; pollution; soils; vegetation; Wood processing.

\section{Introduction}

The advent of industries in the big and small towns in developing countries like Nigeria, is an encouraging phenomenon when viewed from the perspectives of economic and social developments of a nation. Such development prospects, however, can be threatening and leading towards a horrifying environmental disaster, unless industrial wastes are avoided or monitored and disposed properly ${ }^{[1]}$. Soils in the vicinity of industries are classified as polluted or contaminated sites. Soils contaminated with heavy metals are not only a problem with respect to plant nutrition and food chain; they may constitute a direct health hazard as well.

The increasing demand for wood as building materials, furniture, domestic use, sculpture and other artistic designs and decorative purposes, and in various industries, has resulted in increased number of wood processing industries in Delta State, Nigeria. There is a serious lack of information regarding the impact of these wood processing industries on relevant soil quality indices. It is therefore imperative to investigate this. Hence the objective of this paper is to assess the levels of heavy metals and physicochemical properties of the soils in the vicinity of wood processing industries in Delta State, Nigeria.

\section{Study Area}

\section{Materials and Methods}

The study area lies roughly between longitude $5^{\circ} 00$ and $6^{\circ} 45^{\prime}$ East and latitude $5^{\circ} 00$ and $6^{\circ} 00$ North. The vegetation of this area ranges from the mangrove swamps along the coast to evergreen forest and savanna in the north. The temperature is high ranging between $28^{\circ} \mathrm{C}$ and $34^{\circ} \mathrm{C}$ with an average temperature of $30^{\circ} \mathrm{C}$. The rainy season begins in April and lasts till October while the dry season is between November and April. The average rainfall is $266.5 \mathrm{~cm}$ in the coastal area and $190.5 \mathrm{~cm}$ in the northern fringes of the area.

\section{Sampling}

Soil samples were collected from different towns in Delta State. In each town, samples were collected within the premises of three wood processing factories using soil auger. The control (background) samples were obtained from location remote from any industrial zone at the outskirts and far removed from the influence of industrial or traffic activity. At each site, three soil samples per point were collected at depths $0-15 \mathrm{~cm}, 15-30 \mathrm{~cm}$, and $30-45 \mathrm{~cm}$ representing top soil, subsoil and bottom soil respectively. The collected soil samples from each 
depth were bulked and the true representative samples for each depth in each town was taken after a series of coning and quartering ${ }^{[2]}$.

The vegetation samples were collected at the same sites where the soil samples were taken. They were bulked to form composite samples and washed with distilled water to remove soil materials and dusts. They were weighed and transferred into the air-circulated oven operating at $40^{\circ} \mathrm{C} \pm 0.5^{\circ} \mathrm{C}$ until they were dried to constant mass (Ayodele and Gaya, 1994). They were then weighed after cooling in a dessicator to room temperature $29-32^{\circ} \mathrm{C}$ before they were ground with milling machine pretreated with nitric acid to avoid contamination by heavy metals, and then sieved through $2 \mathrm{~mm}$ sieve.

\section{Sample Preparation and Analysis}

The soil samples were air-dried for a period of one week in a well-ventilated laboratory, crushed in a porcelain mortar, and sieved through a $2 \mathrm{~mm}$ stainless sieve. The $<2 \mathrm{~mm}$ fraction was used for the determination of the selected soil properties.

Soil pH was measured in a soil water ratio of 1:2.5 ${ }^{[3] .}$ Total Nitrogen (TN) was annalysed using microkjedahl method ${ }^{[4]}$ Total Organic Carbon (TOC), cation exchange capacity ( $\mathrm{CEC}=\mathrm{Na}+\mathrm{K}+\mathrm{Ca}+\mathrm{Mg}$ ) particular size, and Electrical conductivity were determined using their standard methods respectively ${ }^{[5,6,7,8]}$

Total heavy metals were extracted with $4 \mathrm{M}$ nitric acid at $80^{\circ} \mathrm{C}$ for 8 hours (Bradford et al., 1975). The vegetation samples were digested using $20 \mathrm{~cm}^{3}$ of each acid mixture which comprised nitric acid perchloric acid and sulphuric acid in the ratio of 5:1:0.5. The samples were stirred at 2 hours intervals. All the digests were cooled and filtered through Whatman No. 42 filter paper and the filtrates were analysed for the heavy metals using Atomic Absorption Spectrophotometer (Perkin Elmer Model a Analyst 2002) fitted with deuterium lamp for background correction.

All reagents used in this study were of pure analytical grade, and were checked for possible trace metal contamination. All glasswares were previously soaked in $14 \%$ nitric acid for 24 hours to remove entrained metals, washed with detergents and rinsed with deionized water.

In the elemental analysis by AAS, quality control was monitored using $10 \%$ sample blanks and $10 \%$ sample replicate in each set of sample analysis. The coefficient of variation for replicates were less than $10 \%$ for all elements. Standard reference material 9SRM 2710) was used to have a check on the accuracy of the results. Normally the corresponding results matched within $\pm 1.0 \%$ to $\pm 1.5 \%$

\section{Results and Discussion}

Physicochemical properties of the soil sample.

The results of the physicochemical properties of the soil are presented on Table 1.

Table 1: Physicochemical properties of the soils from all the sites

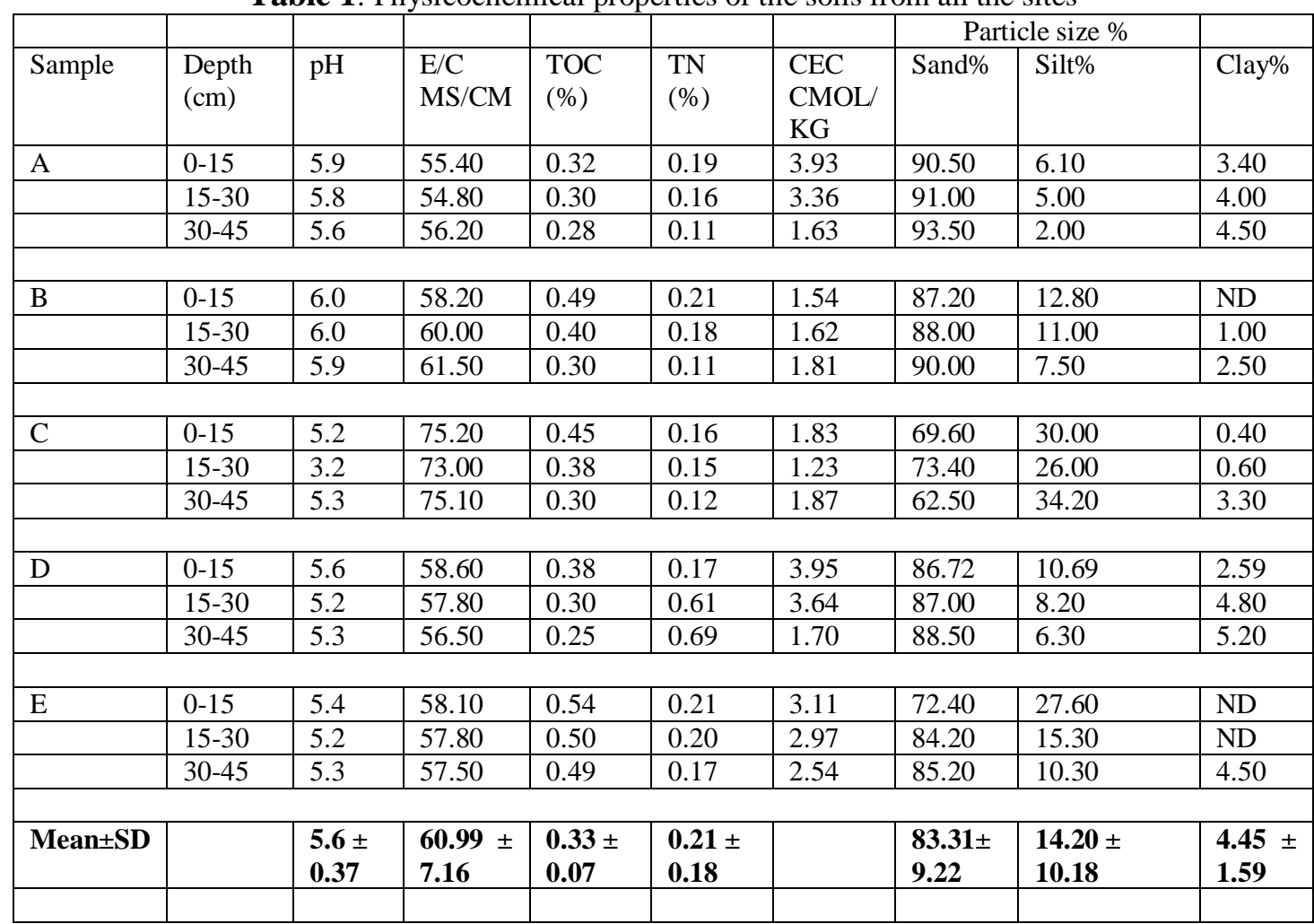


Assessment Of The Effects Of Wood Processing Industries In Selected Parts Of Delta State, Nigeria,

\begin{tabular}{|l|l|l|l|l|l|l|l|l|l|}
\hline Control & $0-15$ & 6.5 & 44.40 & 0.30 & 0.09 & 0.10 & 82.50 & 16.50 & 1.00 \\
\hline & $15-30$ & 6.6 & 42.10 & 0.25 & 0.07 & 1.10 & 80.30 & 16.40 & 3.30 \\
\hline & $30-45$ & 6.8 & 42.10 & 0.25 & 0.06 & 1.20 & 79.40 & 16.60 & 4.00 \\
\hline
\end{tabular}

The $\mathrm{pH}$ values of the soils ranged from 4.9 to 6.0 with a mean value of $5.6 \pm 0.37$. The $\mathrm{pH}$ values suggest that the soils are acidic. The values have no regular trend with soil depth. The $\mathrm{pH}$ values recorded in this study are in the same range with those reported elsewhere ${ }^{[9,10,11]} 10$ The values are however lower than the values reported some other studies ${ }^{[12,13,14,15]}$. At soil pH below 5.0 to 5.5 soluble level of certain metals particularly $\mathrm{Al}^{3+}$ and $\mathrm{Mn}^{2+}$ may be high enough to be biologically toxic ${ }^{[16]}$. Conversely $\mathrm{pH}$ values above 7 are often associated with very low solubility of micronutrient metal cations such as $\mathrm{Zn}^{2+[9]}$. The effect of $\mathrm{pH}$ value below 6 in increasing metal ion activities in soil can be attributed to the decrease in $\mathrm{pH}$ dependent surface charge on oxides of $\mathrm{Fe}, \mathrm{Al}$ and $\mathrm{Mn}$, chellation by organics of metal hydroxide ${ }^{[17]}$. Since studies have shown that there is increase in the availability of many metals with decreasing $\mathrm{pH}$, these $\mathrm{pH}$ values obtained in the soils examined indicate a generally high tendency of high availability of these metals thereby increasing the risk of plant uptake.

The electrical conductivity values ranged from $(\mu \mathrm{S} / \mathrm{cm}) 54.80$ to 75.20 with mean value of $60.99 \pm 7.16$. This result is consistent with that reported in some similar studies ${ }^{[14,18]}$. The implication of high electrical conductivity in soils is that there are reasonable or significant concentration of soluble ionorganic salts resulting to presence of ions. Total Organic Carbon (TOC) ranged from (\%) 0.25 to 0.49 with a mean value of $0.33 \pm 0.07$. The values obtained in this study are consistent with the values reported in other study ${ }^{[14]}$. but lower than the values reported by some other researchers ${ }^{[10,19]}$. The amount of Total Organic Carbon recorded in this study is suggestive of degradation or presence of degradable and compostable materials in the soils. Total Nitrogen ranged from (\%) 0.06 to 0.69 with a mean value of $0.21 \pm 0.18$. These values are in the same range with the values reported in some other studies ${ }^{[20,21]}$ but comparatively higher than the values reported elsewhere ${ }^{[22]}$. The amount of Nitrogen recorded in this study is indicative pf presence of some organic matter. Nitrogen is needed by plants for healthy growth.

The Cation Exchange Capacity values of the soils ranged from (cmol/ $/ \mathrm{kg}) 1.23$ to 3.95. Similar range of values have been reported ${ }^{[23]}$. On the contrary the values observed in this study are very low compared with the values reported in other related studies ${ }^{[10,24,25,26]}$. Both organic and inorganic colloids posses cation Exchange Capacity that contribute to the overall cation exchange of the soil ${ }^{[27]}$. The low values observed in this study may be attributed to the fact that organic colloids may coat inorganic surfaces and hold particles together, making the net cation exchange capacity value lower than what might be predicted if the organic and inorganic contributions were strickly additive ${ }^{[28] .}$ Soil texture was basically sandy loam. In general the soils have a low clay content, so they tend to be permeable.

\section{Heavy Metal Concentration}

The results of the heavy metal analysis are shown on Table 2.

Table 2: Concentration of heavy metals $\left(\mathrm{mgkg}^{-1}\right)$ in the soil profiles at all the sites

\begin{tabular}{|l|l|l|l|l|l|l|l|l|l|}
\hline Sample & Depth(cm) & $\mathrm{Mn}$ & $\mathrm{Pb}$ & $\mathrm{Fe}$ & $\mathrm{Cd}$ & $\mathrm{Cr}$ & $\mathrm{Zn}$ & $\mathrm{Cu}$ & $\mathrm{As}$ \\
\hline $\mathrm{A}$ & $0-15$ & 245.64 & 12.21 & 471.85 & 0.45 & 16.22 & 90.14 & 124.31 & 13.43 \\
& $15-30$ & 239.05 & 11.91 & 469.24 & 0.40 & 16.18 & 89.22 & 124.52 & 20.41 \\
& $30-45$ & 235.79 & 12.91 & 463.54 & 0.39 & 15.92 & 87.92 & 120.80 & 24.20 \\
\hline B & $0-15$ & 139.71 & 16.27 & 341.20 & 0.22 & 19.43 & 87.25 & 114.56 & 11.27 \\
& $15-30$ & 132.56 & 15.82 & 339.19 & 0.20 & 19.35 & 84.33 & 114.38 & 19.48 \\
& $30-45$ & 128.88 & 16.00 & 336.00 & 0.24 & 19.21 & 82.41 & 114.80 & 25.62 \\
\hline $\mathrm{C}$ & $0-15$ & 168.15 & 17.54 & 380.77 & 0.73 & 16.58 & 76.12 & 118.36 & 15.21 \\
& $15-30$ & 167.02 & 16.93 & 379.00 & 0.67 & 16.43 & 74.51 & 117.21 & 21.15 \\
& $30-45$ & 164.00 & 16.11 & 378.85 & 0.69 & 15.85 & 71.19 & 119.91 & 30.18 \\
\hline $\mathrm{D}$ & $0-15$ & 59.79 & 10.85 & 180.28 & 0.12 & 12.78 & 91.33 & 116.23 & 8.67 \\
& $15-30$ & 52.33 & 10.42 & 179.91 & 0.18 & 12.64 & 93.40 & 116.81 & 16.41 \\
& $30-45$ & 47.21 & 8.94 & 161.81 & 0.23 & 12.59 & 94.25 & 123.11 & 25.00 \\
\hline E & $0-15$ & 70.57 & 8.44 & 257.32 & 0.35 & 28.58 & 65.40 & 112.35 & 10.58 \\
& $15-30$ & 72.40 & 9.21 & 256.25 & 0.21 & 28.19 & 54.31 & 119.34 & 20.81 \\
& $30-45$ & 70.41 & 7.63 & 255.41 & 0.19 & 27.88 & 50.18 & 130.95 & 23.56 \\
\hline Mean & & $132.90 \pm$ & $12.69 \pm$ & $272.11 \pm$ & $0.30 \pm$ & $18.52 \pm$ & $79.46 \pm$ & $119.18 \pm$ & $19.07 \pm$ \\
\pm SD & & 4.02 & 0.68 & 3.89 & 0.03 & 0.22 & 3.09 & 3.37 & 7.04 \\
\hline Control & $0-15$ & 8.22 & 0.05 & 5.32 & ND & 0.11 & 2.11 & 4.11 & 0.74 \\
& $15-30$ & 5.50 & 0.05 & 5.30 & ND & 0.11 & 1.91 & 5.11 & 0.76 \\
& $30-45$ & 10.15 & 0.03 & 4.81 & ND & 0.10 & 1.76 & 4.38 & 0.80 \\
\hline Mean & & $7.96 \pm$ & $0.04 \pm$ & $5.14 \pm$ & - & $0.10 \pm$ & $1.936 \pm$ & $4.53 \pm$ & $0.76 \pm$ \\
\pm SD & & 2.34 & 0.01 & 0.29 & & 0.03 & 0.18 & 0.52 & 0.05 \\
\hline
\end{tabular}


The results showed that the heavy metal concentrations were generally higher at the top soil than the sub and bottom soils with a few exceptions in some sites. This is expected since the top soil is the point of contact. Previous studies have shown that surface soils are better indicators of metallic burdens ${ }^{[29,30] .}$ The metal levels of all the sites were significantly higher than the levels observed in the control site which is an indication of significant contribution of the wood processing industries to the elevated levels of the metals in the soils within their vicinities.

The mean concentrations of the heavy metals were $\left(\mathrm{mgkg}^{-1}\right) 132.90 \pm 4.02$ for $\mathrm{Mn}, 12.69 \pm 0.68 \mathrm{for} \mathrm{Pb}$, $272.11 \pm 3.89$ for $\mathrm{Fe}, 0.30 \pm 0.03$ for $\mathrm{Cd}, 18.52 \pm 0.22$ for $\mathrm{Cr}, 79.46 \pm 3.09$ for $\mathrm{Zn}, 119.18 \pm 3.37$ for $\mathrm{Cu}$ and $19.07 \pm 0.4$ for As. Heavy metal concentrations follow the abundance trend of $\mathrm{Fe}>\mathrm{Mn}>\mathrm{Cu}>\mathrm{Zn}>\mathrm{As}>\mathrm{Cr}>\mathrm{Pb}>\mathrm{Cd}$.

Iron has the highest mean concentration in all the sites. This could be associated with ferralitic soil which is characteristic of the study area. Furthermore, it has been confirmed that natural soils contain significant concentrations of iron ${ }^{[31,32,33]}$. Although, it has been suggested that the pollution of the environment by iron cannot be conclusively linked to anthropogenic input but other natural sources as well ${ }^{[34]}$, it can be inferred that since the levels of iron in the soils within the vicinities of the industries, are higher than the levels at the control site, the wood processing industries might have contributed to the increased levels of iron in the soils studied. The levels of iron observed in this study were almost in the same range with the levels reported in some similar studies ${ }^{[35,36]}$. However, these levels are higher than the levels reported in some other related studies ${ }^{[37,38,39]}$. but lower than the levels reported by some other researches ${ }^{[10,13,40,41]}$

Zinc

The mean value of zinc level recorded in this study was $\left(\mathrm{mgkg}^{-1}\right) 79.46 \pm 3.09$. Similar levels have been reported ${ }^{[25,40,42]}$. However, this level was higher than those reported by some other researchers ${ }^{[10,135,]}$ and lower than the levels reported in other related studies ${ }^{[36,43,44]}$

Zinc in form of zinc (ii) oxide is a component of water soluble Arsenic based chemicals used for wood preservation ${ }^{[45]}$. These chemicals have been reported to have caused widespread metal contamination in soils around wood preservation sites due to raw materials handling, spills, deposition of sludge and dripping from freshly impregnated wood or due to leaching from the piles of impregnated wood at these sites by rain water especially under low $\mathrm{pH}$ conditions ${ }^{[46,47,48] .}$ Zinc is also a component of crude oil and machine exhaust ${ }^{[49] .}$

Zinc is essential in plant nutrition. reported that zinc is toxic to plants before it accumulates in sufficient concentration to affect animals and humans. Consequently high concentration of zinc in soil kills or stunts plants growth ${ }^{[50]}$.

Arsenic

The mean value of arsenic $\left(19.07 \pm 7.04 \mathrm{mgkg}^{-1}\right)$ recorded in this study was lower than the levels reported elsewhere in similar studies ${ }^{[51]}$ and higher than the levels reported by some researchers ${ }^{[12,51]}$.

Arsenic is a component of chromated copper arsenate (CCA) which is one of the chemicals used in wood preservation. Boliden salt (BIS - salt) which is usually mixed with zinc sulphate and chromated copper arsenate and used as a wood preservative, contains arsenic in the form of diarsenic pentoxide $\left(\mathrm{As}_{2} \mathrm{O}_{5}\right){ }^{[53]}$. Arsenic is widely distributed in soils and with average concentrations in the range of $1-40 \mathrm{mgkg}^{-1}$ with a mean value of approximately $5 \mathrm{mgkg}^{-1}{ }^{[54]}$. In view of the potential risk of bioaccumulation and toxicity of arsenic ${ }^{[5,56]}$ the geochemical behaviour of arsenic in nature has generated much concern in environmental research in recent years. Arsenic toxicity occurs in the order $\mathrm{As}(\mathrm{III})>\mathrm{As}(\mathrm{V})>$ Organoarsenic compounds. The acute effect of arsenic poisoning by oral intake are intense abdominal pains, nausea, vomiting, diarrhoea resulting from gastrointestinal tract damage and all terminating in coma and death ${ }^{[57]}$. Arsenic has also been implicated in lung cancer ${ }^{[58,59]}$.

Chromium

The mean concentration of chromium was similar to the level reported in another similar study ${ }^{[10]}$ but higher than the level reported in other related study ${ }^{[60]}$.It was however lower than the levels reported by Abollino et al., (2002), Asaah et al., (2005), Urunmatsoma and Ikhuoria (2005) and Iwegbue et al., (2009).

Chromium in form of chromium trioxide $\left(\mathrm{CrO}_{3}\right)$ is a component of CCA and other common water soluble As-based chemicals used for wood preservation ${ }^{[53]}$. In the soil environment, chromium occurs in oxidation states of $\mathrm{Cr}(\mathrm{III})$ and $\mathrm{Cr}(\mathrm{IV})$, which governs its mobility and toxicity ${ }^{[61]}$. In the presence of $\mathrm{Fe}(\mathrm{III})$ in geological environments, the solubility of chromium (III) is ubiquitously controlled by the solid solution $(\mathrm{CrFe})(\mathrm{OH})_{3}{ }^{[62]}$.

Chromium is a micronutrient which is essential to man and animal nutrition. It plays an essential role in glucose tolerance factors thereby preventing diabetes as it acts as insulin ${ }^{[63]}$.

On health problem, chromium is carcinogenic causing cancer of the respiratory organs in chromate workers chronically exposed to chromium containing dusts ${ }^{[64]}$.

Lead 
The mean concentration of lead which was $\left(\mathrm{mgkg}^{-1}\right) 12.69 \pm 0.68$ is almost similar to the levels reported by some other researchers ${ }^{[40,44]}$,

Studies of heavy metals in various Nigerian crude oils have shown them to contain high concentrations of lead among other metals. In addition lead is an additive in our fuel. Therefore the presence of lead could be attributed to its emission through the exhaust of the machines used in the industries.

On toxicity, lead is a neurotoxin and a good example of multimedia pollutant ${ }^{[65] .}$ It has been associated with a wide range of effects which include anaemia, decreased haemoglobin synthesis, cardiovascular disease and disorders in bone metabolism, renal dysfunction and reproduction ${ }^{[66]}$

Cadmium

The levels of cadmium $0.12 \pm 0.73 \mathrm{mgkg}^{-1}$ ) observed in this study are almost in the same range with the levels reported in similar studies ${ }^{[10,52] .}$ Cadmium levels lower than these levels have been reported ${ }^{[40,67]}$. Cadmium levels higher than the levels recorded in this study. Have also been reported ${ }^{[64]}$ It has been indicated that at $\mathrm{pH}$ value below 9, cadmium is present in soil in its mobile form ${ }^{[68,69]}$. With the range of $\mathrm{pH}$ from 4.9 to 6.0 with mean value of $5.6 \pm 0.37$ recorded in this study, it is expected that cadmium would be in soil solution as $\mathrm{Cd}^{3+}$ and in its mobile form it would always be in leachable form in the soils under study.

Cadmium is a "modern metal" having been used increasingly in corrosion prevention, polymer stabilization, electronics and pigment application ${ }^{[70]}$. It is a highly toxic metal which accumulates in the kidney of mammals and can cause kidney malfunction. When inhaled cadmium causes acute bronchitis and pneumonities and inflammation in the liver ${ }^{[71]}$. In Japan, itai-itai disease resulted from increased cadmium uptake from locally consumed rice grown in paddy field irrigated with cadmium containing river water ${ }^{[72]}$.

\section{HEAVY METAL CONCENTRATIONS IN THE VEGETATION SAMPLES}

The concentrations of the heavy metals in the plant samples from all the sites are presented on Table 3.

Table 3: Concentrations of the heavy metals $\left(\mathrm{mgkg}^{-1}\right)$ in the vegetable samples including their means and standard deviations

\begin{tabular}{|l|l|l|l|l|l|l|l|l|}
\hline Site & Mn & $\mathrm{Pb}$ & $\mathrm{Fe}$ & $\mathrm{Cd}$ & $\mathrm{Cr}$ & $\mathrm{Zn}$ & $\mathrm{Cu}$ & $\mathrm{As}$ \\
\hline $\mathrm{A}$ & 27.57 & 4.12 & 59.03 & $\mathrm{ND}$ & 5.32 & 39.25 & 14.24 & 2.56 \\
$\mathrm{~B}$ & 37.24 & 5.91 & 45.20 & $\mathrm{ND}$ & 4.08 & 24.14 & 30.75 & 5.01 \\
$\mathrm{C}$ & 50.99 & 7.08 & 32.12 & $\mathrm{ND}$ & 7.78 & 36.25 & 11.55 & 6.75 \\
$\mathrm{D}$ & 12.25 & 4.22 & 51.13 & $\mathrm{ND}$ & 4.31 & 21.01 & 61.11 & 2.22 \\
$\mathrm{E}$ & 22.28 & 3.74 & 48.02 & $\mathrm{ND}$ & 7.81 & 15.46 & 18.45 & 4.32 \\
Mean \pm & $30.07 \pm$ & $5.01 \pm$ & $47.10 \pm$ & $\mathrm{ND}$ & $5.86 \pm$ & $27.22 \pm$ & $27.22 \pm$ & $4.17 \pm$ \\
SD & 14.78 & 1.42 & 0.29 & & 0.025 & 10.15 & 20.32 & 0.025 \\
Control & 9.21 & 1.04 & 15.02 & $\mathrm{ND}$ & 2.92 & 10.36 & 6.19 & 0.99 \\
\hline
\end{tabular}

All the metals studied were detected in the vegetation except cadmium. Iron with the mean concentration $\left(\mathrm{mgkg}^{-1}\right) 47.10 \pm 0.029$ had the highest level in all the sites. The iron levels observed in this study were above the ranges reported in some other related studies ${ }^{[39,73,74]}$ but lower than the levels reported in other study ${ }^{[75]}$. It is within the typical range in food crops $\left(25-130 \mathrm{mgkg}^{-1}\right)^{[49,76]}$. It is an essential nutrient necessary for chlorophyll synthesis in plants. Iron toxicity has not been of much evidence under natural conditions but when it occurs, the symptoms usually appear as necrotic spots on leaves ${ }^{[77]}$ Iron is an essential nutrient necessary for chlorophyll synthesis in plants and its deficiency in plants, results in distinct yellow or white areas between veins of young leaves leading to spots of dead leaf tissue ${ }^{[77]}$.

Manganese with the mean concentration $30.07 \pm 14.78 \mathrm{mgkg}^{-1}$ was next highest in the vegetable samples. The levels obtained in this study are within the typical range (15-133 $\left.\mathrm{mgkg}^{-1}\right)$ in food crops. Manganese is a micronutrient required by plants for activation of enzymes. Its deficiency in plants causes interveinal yellowing or mottling of young leaves and when in excess, it causes older leaves to have brown spots surrounded by a chlorolic cycle or zone ${ }^{[66]}$. 
The copper and zinc levels with the mean levels $\left(\mathrm{mgkg}^{-1}\right) 27.22 \pm 20.32$ and $27.22 \pm 10.15$ respectively, had the next levels in the vegetation samples. These levels are almost in the same range with the levels reported in another related study ${ }^{[60] .}$ The copper levels obtained in this study were higher than the typical range in food crops, while the zinc levels were within the range. However, the copper levels are lower than level for intolerant plants $\left(100-1000 \mathrm{mkg}^{-1}\right)^{[19,42]}$. Copper as a micronutrient for plants is a component of enzymes and can be taken up by plants and there is possibility of reduced plant growth due to excessive additions ${ }^{[65]}$. Zinc is needed by higher plants for formation of natural plant growth, possibly to absorb water, and synthesis of tryptophan ${ }^{[77] .}$ It is generally referred to as a masculine' element because it is essential for male reproductive activity ${ }^{[77]}$ Copper and zinc are toxic to plants before they accumulate insufficient concentrations to affect animals and man and consequently their high concentrations kill or stunt plants growth ${ }^{[50]}$.

Chromium and lead with the mean concentrations $\left(\mathrm{mgkg}^{-1}\right)$ of $5.86 \pm 0.025$ and $5.01 \pm 1.42$ respectively were the next highest in the vegetation samples. Chromium concentrations in normal and tolerant plants are $\left(\mathrm{mgkg}^{-1}\right) 0.1-0.5$ and $10.0-100.0$ respectively. High concentrations of chromium in plants have been associated with several chlorosis, necrosis and a host of other abnormalities and anatomical disorders ${ }^{[30] \text {. }}$ Lead levels observed in this study were lower than the levels reported in spme similar studies ${ }^{[36,75]}$.

Arsenic with the mean concentration of $4.17 \pm 0.025 \mathrm{mgkg}^{-1}$ had the lowest concentrations in the vegetation samples., arsenic acts to coagulate protein, forms complexes with coenzymes and inhibits the production of adenosine triphosphate (ATP) during respiration and its high-level exposure can cause death ${ }^{[32]}$ Arsenic levels recorded in this study are higher than the typical range in food crops $\left(0.03-2.90 \mathrm{mgkg}^{-1}\right)$.

\section{Soil Plant Transfer Coefficient Or Ratio Of The Heavy Metals}

This is a convenient device to express the relative ease with which elements in soils are taken up above ground tissues by plants. It is obtained by the following expression.

\section{Tf or TR $=\underline{\text { Metal concentration in plant }}$}

Metal concentration in soil

The values indicate the degree of metal accumulation in the plants and the values recorded in this study are presented on Table 4 .

Table 4: Plant Transfer Coefficient or Ratio of the Heavy Metals in Soils from all the Sites

\begin{tabular}{|l|l|l|l|l|l|l|l|l|}
\hline & $\mathrm{Mn}$ & $\mathrm{Pb}$ & $\mathrm{Fe}$ & $\mathrm{Cd}$ & $\mathrm{Cr}$ & $\mathrm{Zn}$ & $\mathrm{Cu}$ & $\mathrm{As}$ \\
\hline $\mathrm{A}$ & 0.11 & 0.34 & 0.13 & - & 0.33 & 0.44 & 0.12 & 0.13 \\
$\mathrm{~B}$ & 0.28 & 0.37 & 0.13 & - & 0.21 & 0.29 & 0.21 & 0.27 \\
$\mathrm{C}$ & 0.31 & 0.42 & 0.08 & - & 0.48 & 0.49 & 0.10 & 0.30 \\
$\mathrm{D}$ & 0.23 & 0.42 & 0.29 & - & 0.34 & 0.23 & 0.51 & 0.13 \\
$\mathrm{E}$ & 0.31 & 0.44 & 0.19 & - & 0.28 & 0.27 & 0.15 & 0.24 \\
\hline
\end{tabular}

The transfer coefficient values of the metals in all the sites ranged from 0.10 to 0.51 with the trend of $\mathrm{Pb}>\mathrm{Zn}>$ $\mathrm{Cr}>\mathrm{Mn}>\mathrm{As}>\mathrm{Cu}>\mathrm{Fe}$. The transfer coefficient values obtained indicate the potential of the plants to absorb metal ions from the soil and deploy them to their foliage.

The values obtained in all the sites for all the metals were in the range that showed medium accumulation $(0.01-1.0)^{[76]}$.

\section{Contamination/Pollution Index (C/P)}

This was calculated as follows, using Lacatus (2000) scheme;

$\mathrm{C} / \mathrm{P}=\underline{\text { Concentration of the metal in soil }}$

Target value

The target value was obtained by using the standard formulated by the Department of Petroleum Resources of Nigeria (DPR) cluster abundant values for maximum allowed concentration (ppm) of heavy metals in soils $(5000 \mathrm{Fe}, 476 \mathrm{Mn}, 85 \mathrm{~Pb}, 36 \mathrm{Cu}, 0.8 \mathrm{Cd}, 100 \mathrm{Cr}, 35 \mathrm{Ni}, 140 \mathrm{Zn}, 20 \mathrm{Co}, 0.3 \mathrm{Hg})^{[78]}$

The contamination/pollution index values are presented on Table 5

Table 5: Contamination/Pollution Index of the Metals in all the Sites

\begin{tabular}{|l|l|l|l|l|l|l|}
\hline & $\mathrm{Pb}$ & $\mathrm{Fe}$ & $\mathrm{Cd}$ & $\mathrm{Cr}$ & $\mathrm{Zn}$ & $\mathrm{Cu}$ \\
\hline $\mathrm{A}$ & 0.14 & 0.09 & 0.52 & 0.16 & 0.64 & 3.42 \\
$\mathrm{~B}$ & 0.19 & 0.07 & 0.28 & 0.19 & 0.60 & 4.02 \\
$\mathrm{C}$ & 0.20 & 0.08 & 0.87 & 0.16 & 0.53 & 3.29 \\
$\mathrm{D}$ & 0.12 & 0.03 & 0.22 & 0.13 & 0.66 & 3.30 \\
$\mathrm{E}$ & 0.10 & 0.05 & 0.31 & 0.28 & 0.40 & 3.36 \\
\hline
\end{tabular}


The concentration/pollution $(\mathrm{C} / \mathrm{P})$ values less than 1 define contamination range while greater than 1 define pollution range. From the values observed in this study only copper was in the pollution range while the rest were in the contamination range. The values for arsenic were not computed since target value for arsenic is not available.

The contamination/pollution index values recorded in this study showed very slight contamination $(<0.10)$ for iron in all the sites, slight contamination $(0.10-0.25)$ for lead and chromium in all the sites except for site $\mathrm{E}$ where it showed moderate contamination. Cadmium showed moderate contamination $(0.26-0.50)$ in sites B, D and E, severe contamination $(0.51-0.75)$ in site A and very severe contamination $(0.76-1.00)$ in site C. Zinc showed severe contamination in all the sites except in site $\mathrm{E}$ where it showed moderate contamination. Copper showed moderate pollution $(2.10-4.00)$ in all the sites.

\section{Conclusion}

The values obtained for the physicochemical characteristics of the soils in this study indicate that the wood processing industries imparted acidic property and contributed to the presence of soluble inorganic salts and degradable or compostable materials as well as organic matters to the soils in their vicinities.

The elevated levels of heavy metals obtained in both the soil and vegetable samples compared with those of the control site is an indication that the industries have significant contribution of these metals to the surrounding environment.

The values obtained for contamination/pollution index suggest that the soil samples were in the range that showed contamination for all the metals except copper which was in the range of moderate pollution. The soil plant transfer coefficient values indicated medium accumulation for all the metals.

Although the metal levels obtained in this study showed some degree of heavy metal soil contamination, they fell within the World Health Organisation (WHO) permissible limits and common range for agricultural soils, residential, commercial, industrial and typical ranges for food crops and so do not pose any significant threat to biota.

\section{References}

[1] F Itanna, Comparative study on soil pollution with toxic substances on farmlands close to old and new industrial sites in Ethiopia. Bull. Chem. Soc. Ethiop. 1998, 12(2): 106-112

[2] I Oguntimehin, and K. Ipinmoroti, Profile of heavy metals from automobile workshops in Akure, Nigeria. J. Environ. Sci. Technol. 2007, 1-8.

[3] B.J. Davey, and M.K Conyers, Determining the pH of acid soils. Soil Sci, 1998, 146: 141-150.

[4] Bermmer J.M. Total nitrogen. In: Black, C.A. (Ed.). Methods of soil analysis. Part 2. Agronomy, 1965, 9: 1149-1178.

[5] D.W. Nelson, and L.E. Sommers, Total carbon, Organic carbon and organic matter 539-571. In page, A.Z. (ed) Methods of soil Analysis.

[6] M.L. Jackson, Soil Chemical Analysis. Prentice Hall, New York. 1960.

[7] G.J. Bouyoucos, Improved hydrometer method for making particle size analysis of soils. Agron. J. 1962, 54: 464-465.

[8] G. Chopra, and C. Kanzar, Analytical Agricultural Chemistry. $2^{\text {nd }}$ Edition, Prentice-Hall, India (1988)

[9] P. Kotoky, B.J. Bora, N.K. Baruah, J. Baruah P. Baruah, and G.C. Borah, Chemical fractionation of heavy metals in soils Around Oil Installations, Assam. Chem. Speciation Bioaval.2003, 15(14): 115-126.

[10] C.M.A. Iwegbue, Assessment of heavy metal speciation in soils impacted with crude oil in the Niger Delta, Nigeria. Chem. Speciation Bioaval. 2011, 23(1): 7-15.

[11] B.W. Tukura, J.A Kagbu, and G.E. Gimba, Effects of pH and total organic carbon (TOC) on distribution of trace metals in Kubanni dam sediments, Zaria, Nigeria. Sci. World J. 2007, 2(3): 1-6.

[12] A. Qishlaqi, F. Moore, and G. Forghani, Impacts of wastewater application on chemnical properties of soils ne arby Khorshk River, Abu-Nasr area, Shiraz. In: The Proceedings of 10th Symposium of Geological Society of Iran (In Farsi). 2006.

[13] O.O. Ogundiran, and T.A Afolabi, Assessment of the physicochemical parameters and heavy metals toxicity of leachates from municipal solid waste open dumpsite. Int. J. Environ. Sci. Tech. 2008, 5(2): 243-250.

[14] P.O. Oviasogie, and E. Omoruyi, Levels of heavy metals and physicochemical properties of soils in foam manufacturing industry. $J$. Chem. Soc. Nig. 2007, 32(1): 102-106.

[15] S.A. Osakwe, and O.B. Otuya, Elemental composition of soils in some mechanic dump sites in Agbor, Delta State, Nigeria Conf. Proceed Chem. Soc. Nig. 2008, 557-559.

[16] M.B. McBride, Environmental Chemistry of Soils. Oxford University Press, New York. 1994, 397pp.

[17] C.O. Adriano, N.S. Bolan, K. Bon-Tun, R. Naidu, D. Lelie, J. Vangronsveld, and W.W. Wenzel, Natural remediation processes: bioavailability interaction in contaminated soils. Symposium No. 42, $17^{\text {th }}$ WCSS $14^{\text {th }}-21$ st August, Thailand. 2002.

[18] C.M.A. Iwegbue, N.O. Isirimah, C. Igwe, and E.S. William, Charecteristics levels of heavy metals in soil profile of automobile mechanic waste dumps in Nigeria. Environmentalist, 2006, 26: 131-137.

[19] C.J. Walsh, Urban impacts on the ecology of receiving water. A frame work for assessment, conservation and restoration. Hydrobiologia 2000, 341: 107-114.

[20] P.O. Oviasogie, and A. Ofomaja, Available $\mathrm{Mn}, \mathrm{Zn}, \mathrm{Fe}, \mathrm{Pb}$ and physicochemical changes associated with soil receiving cassava mill effluent. J. Chem. Soc. Nig. 2007, 32(1): 69-73.

[21] O.I. Osenwata, effects of ablation effluent on the physical and chemical properties of soils. Environ. Monit. Assess, 2009, 1058-1068

[22] S.A. Osakwe, O.B. Otiuya, and E.O. Adaikpoh, Determination, of ph, Cn, Ni, Fe, and hg in the soil of okpia, Delta state, Nigeria Nig, J. Sci. Environ. 2008, 3: 45-49.

[23] C.T.I. Odu, O.F. Esuruoso, I.C. Nowboshi, and J.A. Ogunwala, Environmental Study (soil and Vegetation) of Nigeria Agip Oil Company. Operation Area. A report submitted to Nigeria Agip oil company ltd. Lagos. 1991. 
[24] N.O. Isirimah, An inventory of some Chemical properties of selected soils of Rivewrs State of Nigeria. Proceedings of $15^{\text {th }}$ Annual conference of Soil Science Association Of Nigeria, Kaduna, 1987, 217-233.

[25] O Abollino, M. Aceto, M. Malandrino, E. Mentasti, C. Sarzanini, and F. Petrella, Heavy metals in agricultural soils from Predmont, Italy. Distribution, speciation and chemometric data treatment. Chemosphere, 2002, 49: 545-557.

[26] P.J. Kalisz, Effect of ionic strength on cation exchange capacity of some forest soils. Comm. Soil Sci. Plant Anal. 1986, 17: 9991007.

[27] M.L. Thompson M. Zhang, M. Kakemi, and J.A. Sander, Contribution of organic matter to cation exchange capacity and specific sacrifice area of fractionated soil materials. Soil Sci. 1989, 148(4): 250-257.

[28] J.T. Nyangababo, and J.W. Hamuya, the deposition of Lead, Cadmium, zinc and copper from motor traffic on Bracharianenum and studies 1989, 28: 115-119.

[29] A.A. Amusan, D.V. Ige, and R. Olawale, Characteristics of soils and crops uptake of metals in municipal waste dump sites in Nigeria. J. Hum. Ecol. 2005, 17(3): 167-171.

[30] C.M.A. Ademoroti, Environmental Chemistry and Toxicology. Foludex Press Ltd., Ibadan. 1966, 150-188.

[31] J.O. Duruibe, M.O.C Ogwuegbu, and J.N. Egwurugwu, Heavy metal pollution and human biotoxic effects. Int. J. Physical Sci. 2007, 2(5): 112-117.

[32] P Bhattacharya, A.B. Mukherjee, G. Jacks, and S. Nordqvist, Metal contamination at a wood preservation site. Characterization and experimental studies and remediation. Sci. Total Environ.2002, 290: 165-180.

[33] N.O. Eddy, M.O. Ndibuke, and E.O. Ndibuke, Heavy metals in sediments from Cross River at Oron. African J. Environ. Pollut. Health, 2003, 25-29.

[34] S Uba, A. Uzairu, G.F.S. Harrison, M.L. Balarabe, and O.J. Okunola, Assessment of heavy metals bioavailability in dumpsites of Zaria metropolis, Nigeria. Afr. J. Biotechnol. 2008, 7(2): 122-130.

[35] N.E. Okoronkwo, J.C. Igwe, and E.C. Onwuchekwa, Risk and health implications of polluted soils for crop production. African J. Biotechnol. 2005, 4(13): 1521-1524.

[36] G.R. Bradford, A.L. Page, L.J. Lund, and W. Olmstead, Trace elements concentrations of sewage treatment plant effluents and sludge: Their interactions with soil and uptake by plants. J. Environ. Qual., 1975, 4: 123-127.

[37] S.O. Urunmatosoma, and E.U. Ikhuoria, Effect of leachates (heavy metal content) from solid waste at "Effurun round-about dumpsite" Warri, Nigeria. Chem. Tech. J. 2005, 1: 195-202.

[38] S.A. Osakwe, Heavy metal distribution and bioavailability in soils and cassava (Manihot esculenta Grantz) along Warri - Abraka expressway, Delta State, Nigeria. J. Chem. Soc. Nig. 2009, 34(1): 211-217.

[39] O.A. Akpoveta, S.A. Osakwe, B.E Okoh, and B.O. Otuya, Physicochemical characteristics and levels of some heavy metals in soils around metal scraps dumpsites in some parts of Delta State, Nigeria. J Appl. Sci. Environ. Manage. 2010, 14(): 57-60.

[40] S.A. Osakwe, Distribution of heavy metals in soils around automobile dumpsites in Agbor and environs, Delta State. J. Chem. Soc. Nig. 2010, 35(1): 53-60.

[41] J.E. Etherington, Environmental and Plant Ecology. First Edition. Chichester John Wiley and Sons. 1982, 487

[42] N.O. Eddy, S.A. Odoemelem, and A. Mbaba, Elemental composition of soil in some dumpsites. Elect. J. Environ. Agric. Food Chem. 2006, 1015-1031.

[43] C.O.B. Okoye, and K.E. Agbo, Dispersion pattern of trace metals in soils surrounding solid waste dumps in Nsukka. J. Chem. Soc. Nig. 2011, 36(2): 112-119.

[44] J.E. Warner, and K.R. Solomon, Acidity as a factor in leaching of copper, chromium and arsenic from CCA - treated dimension lumber. Environ. Toxicol Chem. 1990, 9: 1331-1337.

[45] U. Lund, and A. Fobian, Pollution of two soils by arsenic, chromium and copper. Denmark. Geoderma 1991, 49: 83-103.

[46] S Anderson, O. Rasmussen, P. Snilsberg, C.E. Amudsen, and T. Westby, Assessing toxicity and mobilization of impregnated salts at a contaminated site. Fresenius. J. Anal. Chem. 1996, 354: 676-680.

[47] D.C. Adraino, Trace elements in terrestrial environment ( $2^{\text {nd }}$ edition). Springer - Verlay company, New York. 2001.

[48] D.M. Miller, and W.P. Miller, Land application of wastes. Summer, M.E. (Ed.). Handbook of Soil Science. CRC Books, New York. 2000 .

[49] E.G. Uwumarongie, and F.E. Okieimen, Prediction of arsenic, chromium and copper availability to maize seedling in contaminated soil. Conf. Proceed. Chem. Soc. Nig. 2008, 339-345.

[50] V.A. Asaah, A.F. Abimbola, and C.E. Suh, Heavy metal concentrations and distribution in surface soils of the Bassa industrial zone I, Donala, Cameroon. Arabian J. Sci. Engr. 2005, 31(2): 147-158.

[51] H YanChu, Arsenic distribution in soils. In: Nriagu J.O. (ed.) Arsenic in the environment part 1: cycling and characterization. John Wiley. 1994, $17-49$.

[52] D.K. Bhumbla, and R.F. Keefer, Arsenic mobilization and bioavailability in soils. In: Nriagu, J.O. (ed.). Arsenic in the environment part 1: cycling and characterization. New York. John Wiley. 1994, $51-82$

[53] P Bhattacharya, S.H. Frisbie, E. Smith, R. Naidu, G. Jacks, and B. Sarkar, Arsenic in the environment. In: Sarkar, B. (ed.) Handbook of heavy metals in the environments. Marcel Dekker Inc., New York. 2001.

[54] G.L. Waldoh, Health Effects of Environmental Pollution. In: Environmental Studies. The earth as a living planet. Daniel B.B. and Edward, A.K. (eds.) Charles Maril Publication Company. 1978, 359.

[55] A Lafontaine, Health effects of arsenic. In trace metals: Exposure and health effects. CEC and Pargamon Press. 1979, $107-116$.

[56] M Hutton, Human health concern of lead, mercury and arsenic. In: Hulchinson, T.C. and Meema, K.M. (eds.). Lead, mercury, cadmium and arsenic in the environment. Wiley scope, 1987, $85-94$.

[57] M Rashad, and E.A. Shalaby, Dispersion and deposition of heavy metaks around municipal solid waste (MSW) dumpsites, Alexandria, Egypt. American - Eurasean J. Agric. Environ. Sci. 2007, 2(3): 204-212.

[58] R.J. Bartlett, and B. James, Behaviour of chromium in soils III oxidation. J. Environ. Qual. 1979, 8(1): 31-35.

[59] B.M. Sass, and D. Rai, Solubility of amorphous chromium (III) - iron (III) hydroxide solid solutions. Inorg. Chem., 1987, 26: 22282232.

[60] K Schwarts, and W. Mertz, Chromium (III) and the glucose tolerance factor. Arch. Biochem. Biographs. 1959, 85: 292-294.

[61] S Langard, Metals in the Environment. In Waldron, H.A. (ed). Academic Press, London. 1980.

[62] B.J. Alloway, and D.C Ayers, Principles of environmental pollution. Blackie, London. 1990, 140-195.

[63] W.F. Bennett, Nutrient deficiencies and toxicities in crop plants. APS Press, St. Paul, Minnesota. 1993.

[64] E Osabohien, and O.B. Otuya, Heavy metals in soils, tubers and leaves of cassava (Manihot otilisima) plants grown around some oil-spill and gas flaring zones in Delta State, Nigeria. Europ. J. Sci. Res. 2006, 13(1): 53-57.

[65] H.C.H. Hahne, and W. Kroonjte, Significance of $\mathrm{pH}$ and chloride concentration on behaviour of heavy metal pollutants, mercury (II), cadmium (II), zinc (II) and lead (II). J. Environ. Qual. 1973, 2: 444-450. 
[66] M.A. Chaudri, M.G. Celine, S.H. Allain, L.M. Adams, McGrath, P.S. and Chamber, J.B. Heavy metals in environment: cadmium content of wheat grains from long term field experiment with sewage sludge. J. Environ. Qual. 30: 1575-1580 (2001)

[67] Alloway B.J. Biovailability of Element in Soils. Elsevier Inc. 2005, 347-371.

[68] H.N. McFerland, Pulmonary effects of cadmium. In: Mennean, J.E. (ed.) Cadmium Toxicity. Dekker. 1979, 113-132.

[69] D Purves, Trace elements contamination of environment. Elsevier - Amsterdam, Oxford - New York. 1985.

[70] S.A. Osakwe, Chemical speciation and mobility of some heavy metals in soils around automobile waste dumpsites in Northern part of Niger, Delta, South Central, Nigeria. J. Appl. Sci. Environ. Manage. 2010, 14(4): 123-130.

[71] T.T. Ayodele, and U.M. Gaya, Determination of lead in street dust to index its pollution in Kano municipal. Spectrum J. 1994, 1: 92 95.

[72] A.O. Ano, S.A. Odomelam, and P.O. Ekwueme, lead and Calcium levels in soils and cassava 9manihot esculenta grants) along Enugu-portHarcourt Express way in Nigeria. Elec J.Environ. Agric food chem.. 2007, 6(5) 2024-2031.

[73] Kabate .Pendicas it.Trace Elements in soils and plants. (2 ${ }^{\text {nd }}$ edition0 C.R.G Press, Raton F.L. 1992.

[74] C.M.A Iwegbue, F.E. Egobueze, and K Opuene, Preliminary assessment of heavy metals levels of soils of an oil field in the Niger Delta, Nigeria. Int. J. Environ. Sci. Tech. 2006, 3(2): 167-17.

[75] H.G. Gauch, Inorganic plants nutrition. Dowder: Hutchinson and Ross Inc., Stroudsburg, Pennyslvania. 1972, 448.

[76] DPR . Environmental guidelines and standards for petroleum industry in Nigeria (Revised Edition). Department of Petroleum Resources. Ministry of Petroleum and Mineral Resources 2002. 